\title{
Agronomic Performance of Soybean Intercropped With Cover Crops and the Effects of Lime and Gypsum Application
}

\author{
Osvaldo Jose Ferreira Junior ${ }^{1}$, Leandro Bortolon ${ }^{2}$, Emerson Borghi ${ }^{3}$, Elisandra Solange Oliveira Bortolon ${ }^{2}$, \\ Francelino Peteno de Camargo ${ }^{2}$, Rubens Ribeiro da Silva ${ }^{1}$, Margarete Nicolodi ${ }^{4} \&$ Clesio Gianello ${ }^{4}$ \\ ${ }^{1}$ Universidade Federal do Tocantins, Faculdade de Agronomia, Gurupi, Brazil \\ ${ }^{2}$ Embrapa Pesca e Aquicultura, Palmas, Brazil \\ ${ }^{3}$ Embrapa Milho e Sorgo, Sete Lagoas, Brazil \\ ${ }^{4}$ Universidade Federal do Rio Grande do Sul, Faculdade de Agronomia, Porto Alegre, Brazil \\ Correspondence: Leandro Bortolon, Embrapa Pesca e Aquicultura, Palmas, TO, Brazil. Tel: 55-3229-7825. \\ E-mail: leandro.bortolon@embrapa.br
}

Received: November 8, $2017 \quad$ Accepted: March 5, $2018 \quad$ Online Published: April 15, 2018

doi:10.5539/jas.v10n5p240 URL: https://doi.org/10.5539/jas.v10n5p240

The research is financed by CNPq, Embrapa and Universidade Federal do Tocantins. Soil and plant analysys were performed by Laboratório de Solos da Universidade Federal do Rio Grande do Sul.

\begin{abstract}
Soybean is the major crop in the Brazilian Cerrado region. Tocantins state has been increasing soybean production mostly into degraded pasture. However, cover crops such as forages crops are important to implement in regional soybean agricultural systems to increase systems resilience due to climate variability. There is a lack of information regarding to agronomic performance of soybean intercropped with cover crops under no-tillage. The experimental design was randomized complete blocks with four replications in factorial $7 \times 2$. Seven soybean cultivation systems were tested: 1) soybean intercropped with Urochloa brizantha cv. Marandu; 2) soybean intercropped with Urochloa ruziziensis; 3) soybean intercropped with Panicum maximum cv. Mombaça; 4) soybean intercropped with Panicum infestans cv. Massai; 5) soybean intercropped with Pennisetum americanum; 6) soybean followed by Pennisetum americanum; and 7) soybean and fallow. Two soil acidity and amelioration were tested: 1) with lime and gypsum application; 2) without lime and gypsum application. Soybean grain yield, plant height and number of pods per plant were different. Soybean grain yield were higher with lime ad gypsum application. The highest soybean plants height were observed in the treatments where lime and gypsum were applied, and with soybean intercropped with $P$. maximun and Millet. Soybean number of pods was positively affected $P$. infestans intercropped with soybean. There was no significant difference among treatments for mass per 100 seeds. Cover crops showed suitable to increase agronomic performance of soybean.
\end{abstract}

Keywords: no-till, cover crops, tropical forages

\section{Introduction}

Soybean is the major crop in Brazil and the country is one of the major producers worldwide (Batisti \& Sentelhas, 2017). The state of Tocantins along with the states of Maranhão, Piauí and Bahia, located in the Northern Cerrado region in Brazil, also denominated MATOPIBA region is considered one of the last agriculture frontier worldwide and, the region is responsible for $9.7 \%$ of national soybean production (CONAB, 2014). Tocantins state has great potential to increase soybean cropped areas mostly in both fallow and degraded pasture areas. The degraded pasture is due to several factors such as incorrect soil preparation, incorrect method and choice of pasture implementation, use of low pasture seed quality, inadequate pasture management regarding to nutrient application (Peron \& Evangelista, 2004). Another reason for this problem is low pH and high aluminum saturation in the exchange complex, resulting in decreased nutrient availability, impairing the growth and development of the root system (Fageria \& Nascente, 2014).

Liming is a technique that benefits the soil, because it neutralizes the aluminum, raises the $\mathrm{pH}$ and provides calcium and magnesium, contributing to the increase of base saturation and nutrient availability (Fageria \& 
Nascente, 2014). Gypsum is important as soil amelioration by reducing Al saturation and increases the amount of calcium and sulfur in subsurface, providing to the soil a better environment for the development of the roots in deeper layers (Fageria \& Nascente, 2014). Areas of where one major crop is adopted are usually more affected by reducing soil quality, affecting mostly soil physical, chemical and biological properties, leading to low biomass production, low root development and biomass and consequently decrease crop yield (Sievers \& Cook, 2018; Tormena et al., 2016) and increase in the spread of weeds, insects and pests (Nolan et al., 2017).

To improve agricultural systems sustainability, the annual biomass addition into agricultural systems is necessary and cover crops with using forage species can play an important role to improve the agricultural systems sustainability. Integrated crop-livestock (ICL), can be an important tool to diversification, crop rotation, intercropping or succession in MATOPIBA region, mostly to the advantage of to maintain soil surface covered throughout the year and leading the systems toward sustainability (Alves et al., 2017; Pariz et al., 2017; Braz et al., 2012). The use of forage species as cover crops coupled with no-tillage increases farmer profitability and improve the environmental quality by increasing soil quality (Carvalho et al., 2011; Alves et al., 2017; Pariz et al., 2017). Use of forage as cover crops or in the ICL improve soil structure, increase soil organic carbon and water available water mostly because forages are able to produce high amount of annual biomass into the soil, either aboveground and belowground biomass (Franzluebbers et al., 2014; Lemaire et al., 2014; Moore et al., 2014; Maltas et al., 2009). Although there are several species to use as cover crop and to implement in ICL, the agronomic performance of the soybean intercropped with forage species is gap of knowledge that must be filled. Therefore, we aimed to investigate the soybean agronomic performance intercropped with five major forage species used in MATOPIBA region and the influence of lime and gypsum application on soybean and forage production.

\section{Material and Methods}

The experiment was carried out at the Experimental Station of the Universidade Federal do Tocantins (Gurupi, Tocantins state) latitude $11^{\circ} 43^{\prime} 45^{\prime \prime}$ South, longitude $49^{\circ} 04^{\prime} 07^{\prime \prime}$ West and altitude of $278 \mathrm{~m}$, in the 2013/2014 crop season. Climate in the region is defined as Aw, characterized by tropical humid climate, with dry winter and maximum rains in summer, and average annual temperature of $26.1^{\circ} \mathrm{C}$ (Köppen, 1948).

The plots were stablished in 2012 in Oxisol with a medium texture (EMBRAPA, 2014). Detail of the experiment implementation is detailed described in (Andrade et al., 2017). The area was under degraded pasture for 15 years. A randomized complete block design, with four replications in $7 \times 2$ factorial. The first factor consisted of seven soybean systems: 1) soybean intercropped with Urochloa brizantha cv. Marandu (Soybean $+U$. brizantha); 2) soybean intercropped with Urochloa ruziziensis (Soybean $+U$. ruziziensis); 3) soybean intercropped with Panicum maximum cv. Mombaça (Soybean + P. maximum); 4) soybean intercropped with Panicum infestans $\mathrm{cv}$. Massai (Soybean $+P$. infestans); 5) soybean intercropped with Pennisetum americanum (Soybean+Millet); 6) soybean followed by Pennisetum americanum (Soybean/Millet); and 7) soybean and fallow (Soybean). Two soil acidity and amelioration were tested: 1) with lime and gypsum application (LG); 2) without lime and gypsum application (no LG). Plots were $21 \mathrm{~m}$ long and $12 \mathrm{~m}$ wide with subplots with $21 \mathrm{~m}$ long and $6 \mathrm{~m}$ wide. Soil samples were taken in 2012 prior the plot implantation at $0-20 \mathrm{~cm}$ soil depth. Soil analysis results (Embrapa, 1997) were: $\mathrm{pH}$ in $\mathrm{CaCl}_{2}=3.98 ; \mathrm{P}=1.09 \mathrm{mg} \mathrm{kg}^{-1}$ and $\mathrm{K}=32.0 \mathrm{mg} \mathrm{kg}^{-1}$ (Mehlich-1) $\mathrm{Cu}=0.90 \mathrm{mg} \mathrm{kg}{ }^{-1}, \mathrm{Zn}=$ $0.30 \mathrm{mg} \mathrm{kg}{ }^{-1}$ and $\mathrm{Mn}=12.20 \mathrm{mg} \mathrm{kg}$ (Mehlich-1); $\mathrm{Ca}=0.17 \mathrm{cmol}_{\mathrm{c}} \mathrm{kg}^{-1} ; \mathrm{Mg}=0.06 \mathrm{cmol}_{\mathrm{c}} \mathrm{kg}^{-1}$ and $\mathrm{Al}=0.75$ $\mathrm{cmol}_{\mathrm{c}} \mathrm{kg}^{-1}$ (Ammonium acetate) organic matter $=15.40 \mathrm{~g} \mathrm{~kg}^{-1}$ (Walkley Black) Sand $=690 \mathrm{~g} \mathrm{~kg}^{-1} ;$ Silty $=100 \mathrm{~g}$ $\mathrm{kg}^{-1}$ and Clay $=210 \mathrm{~g} \mathrm{~kg}^{-1}$. Based on soil testing results, in 2012 were applied lime and gypsum in the sub plots with LG at the rate of $2500 \mathrm{~kg} \mathrm{ha}^{-1}$ and $1000 \mathrm{~kg} \mathrm{ha}^{-1}$ of lime and gypsum, respectively, which were the recommended rates of lime and gypsum for soybean production in the Cerrado region of Brazil (Sousa \& Lobato, 2004). In addition, $250 \mathrm{~kg} \mathrm{ha}^{-1}$ of $\mathrm{P}_{2} \mathrm{O}_{5}, 100 \mathrm{~kg} \mathrm{ha}^{-1}$ of $\mathrm{K}_{2} \mathrm{O}$ and $30 \mathrm{~kg} \mathrm{ha}^{-1}$ of micronutrients as fritted trace elements (FTE-S: $3.9 \%$; B: 1.8\%; Cu: 0.85\%; Mn: 2.0\% and Zn: $9.0 \%$ ) were surface broadcast applied in all plots to build up soil fertility to adequate level. After application all nutrients and lime and gypsum were incorporated into the soil. Soybean cultivar Embrapa Sambaíba was planted at $0.45 \mathrm{~m}$ row spacing. Forages species intercropped with soybean were oversowed when soybean were at reproductive stage R5 (Litch, 2014). Forage seeds were applied at rate of $5 \mathrm{~kg} \mathrm{ha}^{-1}$ for viable pure seeds, and P. americanum seeds were applied at rate of $15 \mathrm{~kg} \mathrm{ha}^{-1}$ (Machado \& Assis, 2010; Pacheco et al., 2009). The 2012/2013 crop season was intended to stablish no-tillage in all plots. Forages aboveground biomass (DM) were evaluated 30 days prior soybean planting by sampling four randomized rectangular samples $(1.0 \mathrm{~m} \times 0.25 \mathrm{~m})$ in the central plot. Samples were placed to dry in oven with air-forced circulation at $65^{\circ} \mathrm{C}$ for $72 \mathrm{~h}$, weighed and calculated to express the results in $\mathrm{tha}^{-1}$. Forages were killed using $1.8 \mathrm{~kg} \mathrm{ha}^{-1}$ of glyphosate immediately after forages sampling were concluded. 
In the crop season of 2013/2014, soybean cultivar SYN 1279 RR was sowed. Soybean was inoculated with Bradyrhizobium japonicum and sown with spacing $0.45 \mathrm{~m}$ row space. Forages species intercropped were oversowed when soybean were at reproductive stage R5, which $50 \%$ of soybean plants had pod filling (Litch, 2014). Forage seeds were applied at rate of $5 \mathrm{~kg} \mathrm{ha}^{-1}$ for viable pure seeds, and $P$. americanum seeds were applied at rate of $15 \mathrm{~kg} \mathrm{ha}^{-1}$ (Machado \& Assis, 2010; Pacheco et al., 2009).

Soybean agronomic performance were evaluated in two reproductive stages. Soybean nutrients status at reproductive stage R2 were evaluated by sampling randomized 15 branches per plot. Samples were placed in the oven to air-forced dry at $65{ }^{\circ} \mathrm{C}$ for $72 \mathrm{~h}$. Plant macronutrients (P, K, S, Ca and Mg) were analyzed by nitric acid and perchloric acid digestion according to the methodology of Malavolta et al. (1997). The collected leaves were stored in paper bags and taken to the refrigerator. Soybean growth was evaluated at reproductive stage R8. We evaluated plant height ( $\mathrm{PH})$, number of pods per plant (NP), mass of 100 grains (GW) and grain yield (GY). The PM was recorded measuring 10 randomized soybean plants per plot from the soybean plant stem base to the apex. The NP and GW were recorded in 10 soybean plants per plot randomized harvested, and GW was recorded using a digital scale. The GY was determined within $19 \mathrm{~m}$ long and 2 wide in the central plot using plot combine. Afterward, grains were weighed to determine yield, with values corrected for $13 \%$ of moisture content. Daily rainfall, air temperature and relative humidity were recorded at a weather station about $2.0 \mathrm{~km}$ from the experimental site and presented monthly for the growing season (Figure 1).

The data were analyzed to analysis of variance and the means were compared using the Tukey's test, at 5\% probability using the software Assistat 7.7 (Silva \& Azevedo, 2016).

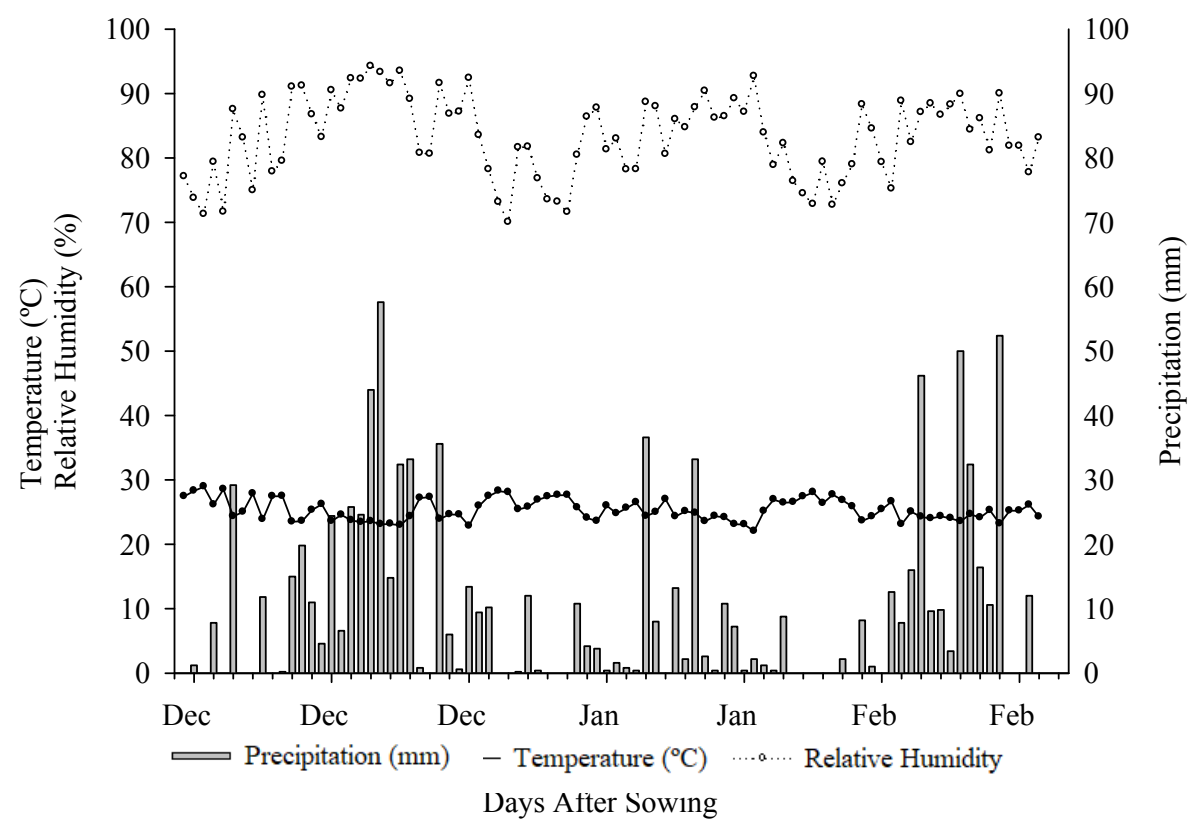

Figure 1. Monthly air temperature, relative humidity and precipitation in the growing season (December, 2013 to February, 2014)

\section{Result and Discussion}

Forages aboveground biomass (DM) in each treatment evaluated 30 days before soybean planting ranged from $2.4 \mathrm{t} \mathrm{ha}^{-1}$ (Soybean/Millet no LG and LG) to $17.7 \mathrm{t} \mathrm{ha}^{-1}$ (Soybean+P. maximum LG), with total average of $6.4 \mathrm{t}$ $\mathrm{ha}^{-1}$ of forage aboveground biomass (Table 1). Millet was the cover crop that yielded the lowest aboveground biomass. Millet lowest biomass production was affected by seed quality. Hence, Millet establishment was affected in both intercropped and sowed after soybean harvest due to low topsoil moisture and high air temperatures. Analysis of variance showed that forage aboveground biomass varied among species which was expected, but no differences were found among the application of lime and gypsum nor the interaction among them (Table 2). Millet is one of the most cover crop used in the Cerrado region of Brazil. Millet vigorous initial growth can be an important forage to anticipate animal stocking compared to perennial forages, once Millet is 
prompt to be grazed in 30 days after seeds emergence while the other forages in this study takes at least 45 days after seeds emergence (Machado \& Assis, 2010; Andrade et al., 2017). Based on the inherent differences among Millet and perennial forages investigated, lower Millet DM compared to Soybean $+P$. maximum can be explained by the longer growth cycle by Soybean $+P$. maximum. In addition, Soybean $+P$. maximum grass has lower number of tiller, larger leaf area, conferring the higher value of DM than Millet. Cover crop residue addition to soil creates an environment extremely favorable to plant growth, contributing to stabilization, recovery or maintenance of physical, chemical and biological soil characteristics (Franzluebbers et al., 2014; Pariz et al., 2017). As a result, it improves the soil quality. In addition to the soil cover provided by residues, is an important source of nutrients to farming systems, in view of plants up takes it in soil subsurface layers and being subsequently released on surface by its decomposition (Krutzmann et al., 2013). In the Cerrado of Tocantins state, climate conditions are favorable for the increase of decomposition rate and the short rainy season difficult soil surface cover. In consequence, the production and maintenance of plant cover on soil surface are more complex (Mata et al., 2011). The decomposition can be 10 times more accelerated in tropical regions and subtropical than temperate regions (Boer et al., 2008).

Table 1. Forages aboveground biomass intercropped with soybean affected by soil acidity correction and soil amelioration by the application of lime and gypsum ${ }^{\S}$

\begin{tabular}{|c|c|c|c|c|c|c|c|}
\hline \multirow{2}{*}{$\begin{array}{l}\text { Soil }{ }^{\S \S} \text { Correction/ } \\
\text { Amelioration }\end{array}$} & \multicolumn{6}{|c|}{ Forage species intercropped with soybean } & \multirow[b]{2}{*}{ Mean } \\
\hline & $\begin{array}{l}\text { Soybean+ } \\
\text { U. brizantha }\end{array}$ & $\begin{array}{l}\text { Soybean+ } \\
\text { U. ruziziensis }\end{array}$ & $\begin{array}{l}\text { Soybean }+ \\
\text { P. maximum }\end{array}$ & $\begin{array}{l}\text { Soybean }+ \\
\text { P. infestans }\end{array}$ & $\begin{array}{l}\text { Soybean+ } \\
\text { Millet }\end{array}$ & $\begin{array}{l}\text { Soybean/ } \\
\text { Millet }\end{array}$ & \\
\hline & \multicolumn{7}{|c|}{ 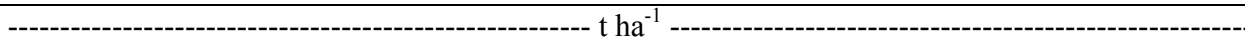 } \\
\hline no LG & 5.3 & 5.5 & 14.2 & 5.7 & 2.6 & 2.4 & $6.8 \mathrm{a}$ \\
\hline LG & 5.9 & 6.1 & 17.7 & 5.9 & 2.9 & 2.4 & $6.0 \mathrm{a}$ \\
\hline Mean & $5.6 \mathrm{BC}$ & $5.8 \mathrm{~B}$ & $15.9 \mathrm{~A}$ & $5.8 \mathrm{~B}$ & $2.8 \mathrm{CD}$ & $2.4 \mathrm{D}$ & 6.4 \\
\hline
\end{tabular}

Note. ${ }^{\S}$ Means followed by the same lowercase letters in the columns and uppercase letters in the rows are not significant (Tukey $P=0.05$ probability level; ${ }^{\S}$ no LG (no lime and no gypsum application), LG (lime and gypsum application).

Table 2. Analysis of variance (F values) of forages aboveground biomass intercropped with soybean (DM), soybean plant height (PH), number of pods per plant (NP), grain weight (GW) and grain yield (GY) affected by soil acidity correction and soil amelioration by the application of lime and gypsum

\begin{tabular}{llllll}
\hline Factor & DM & PH & NP & GW & GY \\
\hline Soybean+Forages (S) & $48.8^{* *}$ & $3.64^{* *}$ & $3.04^{*}$ & $1.62^{\text {ns }}$ & $1.51^{\text {ns }}$ \\
Soil Correction (C) & $2.35^{\text {ns }}$ & $17.8^{* *}$ & $0.02^{\text {ns }}$ & $0.07^{\text {ns }}$ & $69.3^{* *}$ \\
S X C & $0.89^{\text {ns }}$ & $1.28^{\text {ns }}$ & $1.00^{\text {ns }}$ & $1.25^{\text {ns }}$ & $1.31^{\text {ns }}$ \\
C.V. $(\%)$ & 30.1 & 9.9 & 26.2 & 5.8 & 14.7 \\
\hline
\end{tabular}

Note. * Significant at the $P=0.05$ probability level; ** Significant at the $P=0.01$ probability level; ${ }^{\text {ns }}$ no significance; C.V. = Coefficient of variance.

Soybeans PH varied among treatments (Table 3). Soybean $+P$. maximum and Soybean+Millet presented highest soybean plant height. The lowest soybean plant height was observed in Soybean/Fallow (Table 3). For soil correction and amelioration, treatments with lime and gypsum were obtained higher plant height averages compared to no soil correction and amelioration application.

Soybean NP was not affected by soil correction and amelioration (Tables 2 and 3). However, there was a significant difference between forages intercropped with soybean, in which Soybean $+P$. infestans was the highest NP found and Soybean + U. ruziziensis was the lowest NP observed.

The number of pods per plant is an important agronomic component related with crop yield, and it is directly influenced by the factors that affect plant growth and branching, as well as climatic conditions during flowering and early pod formation (Pedersen \& Lauer, 2004). Genetic and physiological potential of soybean, considering an isolated plant, has allowed the production of large NP, although under commercial farming conditions, NP is much lower due to competition between plants and variations in climatic conditions (Mancin et al., 2009). According to Pacheco et al. (2013), and Carvalho et al. (2011), grasses have low rate of residue degradation and 
emphasize that $U$. ruziziensis has higher potential of degradation than $U$. brizantha and other forages. This implies more rapid release of nutrients of $U$. ruziziensis, such as potassium, nitrogen, phosphorus and calcium. Calonego et al. (2012) stressed out that nutrient release from forages residue degradation occours more intensely in the first 45 days and Chioderoli et al. (2012) demonstrate that forage residues kept in the soil surface also benefits soil physical structure, which facilitates growth and nutrients absorption by the roots. The rapid release of nutrients due to the high rate of degradation may be the possible cause of the low amount of pods per plant, because the plant may have increase its vegetative development, and in the reproductive stage the reserve has been exhausted and the plant could not express all productive potential (Pedersen \& Lauer, 2004; Singer et al., 2008).

The weights of 100 grain $(\mathrm{GW})$ are presented in Table 3. We observed that soybean was not influenced by the intercropping, as well as, soil correction and soil amelioration also did not promote significant difference. The $\mathrm{GW}$ is the production component that presents the lowest percentage of variation growing in altered environment (Carvalho et al., 2004). Soybean plant tends to form few grains, rather than many and poorly formed, because the main purpose of the species is the propagation (Pedersen \& Lauer, 2004).

The absence of statistical significance to the components of production (NP, and GW) for soybean intercropped with forages can be attributed to the possible decomposition and mineralization of similar forage residue (Garcia et al., 2014). Some production components such as the number of pods and weight of grains may not be directly associated to productivity, being attributed to the variability of plant stand and the competition for components as light and physical space (Pacheco et al., 2009).

Grain yield was only affected by soil correction and soil amelioration (Table 3 ) in which treatments with lime and gypsum showed higher grain yields. Soybean yield in the treatments without lime and gypsum ranged from $2050 \mathrm{~kg} \mathrm{ha}^{-1}$ (Soybean/Fallow) to $2566 \mathrm{~kg} \mathrm{ha}^{-1}$ (Soybean/Millet), and soybean yield in the treatments with lime and gypsum ranged from $2609 \mathrm{~kg} \mathrm{ha}^{-1}$ (Soybean/Fallow) to $3393 \mathrm{~kg} \mathrm{ha}^{-1}$ (Soybean $+P$. infestans), respectively (Table 3). Forage intercropped with soybean did not affected soybean yield. These results corroborate with Santos et al. (2013) and Silva et al. (2015), which evaluated soybean intercropped with forages in integrated crop-livestock, also did not observed differences between treatments for agronomic characteristics; however, the results were different those found by Bahry et al. (2013), were a significant difference was only found for plant height. In several studies where advantages of forages as cover crops are shown, a strong relationship with soil attributes mostly in the soil chemistry, soil physics and some crop health were demonstrated to be improved by cover crop adoption (Pariz et al., 2014; Franzluebbers et al., 2014). However, in some cases, the benefits stressed out previously do not reflect in grain yield (Guimarães et al., 2003; Carvalho et al, 2011; Muraishi et al., 2005). To better obtain the benefits in increase of crop yield, time must be taken account for more appropriate measures the effects of forages as cover crops (Machado \& Assis, 2010).

The no significant differences between the intercropping systems in this study shows that the no-till tends to improve the productive conditions of agroecosystems over years with positive effects on soybean grain yield (Passos et al., 2015). Other authors (Pauletti et al., 2003; Pereira et al., 2011) obtained similar results, absence of difference between systems, in the first year. Santos et al. (2006) comparing four soil management systems and three rotation systems, verified that in the first years, regardless of rotation, soybean under no-till and minimum tillage did not differ from the conventional tillage system for grain yield, weight of 1.000 grains and plant stature. The factors that contribute to increase soybean yield in no-tillage system are related to the physical, chemical and biological improvement of soil (Fidelis et al., 2003). No-tillage system, well managed, has high potential to improve quality of soil profile (Spera et al., 2011), increasing contents of organic matter by better nutrient cycling capacity (Yagi et al., 2005; Izumi et al., 2009). Crops intercropped with forages reflect positively on soil properties, for high volume of roots in soil depth and production of organic matter increased by recycling of nutrients (Calonego et al., 2011; Silva et al., 2015). The reason for the low productivity in the plots without lime and gypsum probably occurred due to the low soil fertility with base saturation equal to $6.71 \%$. Sousa \& Lobato (2004) recommend that the base saturation should be close to $60 \%$ in order to provide essential basic cations; however, soybean did not respond to increase base saturation in highly weathered soils which high yields are obtained in base saturation ranging from 20-70\% (Fageria \& Nascente, 2014). Possibly, in areas where liming and gypsum was carried out, the base saturation was high, providing more cations to soil solution.

The values of $F$ and levels of significance of macronutrients Phosphorus (P), Potassium (K), Calcium (Ca), Magnesium ( $\mathrm{Mg}$ ) and Sulfur (S) in soybean leaf sampled at stage R2 affected by forages intercropped and application of lime and gypsum are shown in Table 4. Considering the interaction of cropping systems versus soil correction, there was no significance, characterizing independence of factors. The soil correction levels did not influence on the expression of studied systems, and thus, the factors were studied in isolation. 
Table 3. Soybean plant height (PH), number of pods per plant (NP), grain weight (GW) and grain yield (GY) of soybean intercropped with forages affected by soil acidity correction and soil amelioration by the application of lime and gypsum ${ }^{\S}$

\begin{tabular}{|c|c|c|c|c|c|c|c|c|c|c|c|c|}
\hline \multirow{2}{*}{$\begin{array}{l}\text { Forage species intercropped } \\
\text { with soybean }\end{array}$} & \multicolumn{12}{|c|}{ Soil Correction/Amelioration ${ }^{\S \S}$} \\
\hline & "No LG & LG & Mean & No LG & LG & Mean & No LG & LG & Mean & No LG & LG & Mean \\
\hline & \multicolumn{3}{|c|}{ - } & \multicolumn{3}{|c|}{------ NP (n) ------- } & \multicolumn{3}{|c|}{------ GW (g) ------- } & \multicolumn{3}{|c|}{--- GY $\left(\mathrm{kg} \mathrm{ha}^{-1}\right)$---- } \\
\hline Soybean $+U$. brizantha & 0.55 & 0.64 & $0.60 \mathrm{ab}$ & 72 & 61 & $66 \mathrm{ab}$ & 16.4 & 16.3 & 16.3 & 2084 & 3075 & 2579 \\
\hline Soybean $+U$. ruziziensis & 0.54 & 0.58 & $0.56 \mathrm{ab}$ & 51 & 53 & $52 \mathrm{~b}$ & 16.9 & 17.2 & 17.0 & 2149 & 3215 & 2682 \\
\hline Soybean $+P$. maximum & 0.57 & 0.72 & $0.64 \mathrm{a}$ & 67 & 58 & $63 \mathrm{ab}$ & 16.9 & 16.4 & 16.7 & 2156 & 3252 & 2704 \\
\hline Soybean $+P$. infestans & 0.56 & 0.64 & $0.60 \mathrm{ab}$ & 86 & 79 & $83 \mathrm{a}$ & 15.5 & 16.1 & 15.7 & 2281 & 3394 & 2837 \\
\hline Soybean+Millet & 0.61 & 0.62 & $0.62 \mathrm{a}$ & 60 & 63 & $61 \mathrm{ab}$ & 17.0 & 15.8 & 16.4 & 2057 & 2935 & 2496 \\
\hline Soybean/Millet & 0.55 & 0.61 & $0.58 \mathrm{ab}$ & 62 & 89 & $76 \mathrm{ab}$ & 15.4 & 16.4 & 15.9 & 2566 & 2867 & 2716 \\
\hline Soybean/Fallow & 0.50 & 0.54 & $0.52 \mathrm{~b}$ & 81 & 78 & $79 \mathrm{ab}$ & 16.6 & 16.0 & 16.3 & 2050 & 2609 & 2330 \\
\hline Mean & $0.55 \mathrm{~B}$ & $0.62 \mathrm{~A}$ & 0.59 & 68 & 69 & 68.5 & 16.4 & 16.3 & 16.3 & $2192 \mathrm{~B}$ & $3049 \mathrm{~A}$ & 2620 \\
\hline
\end{tabular}

Note. ${ }^{\S}$ Means followed by the same lowercase letters in the columns and uppercase letters in the rows are not significant (Tukey $P=0.05$ probability level; ${ }^{\S}$ no LG (no lime and no gypsum application), LG (lime and gypsum application).

Table 4. $\mathrm{F}$ value and significance level of phosphorus $(\mathrm{P})$, potassium $(\mathrm{K})$, calcium $(\mathrm{Ca})$, magnesium $(\mathrm{Mg})$ and sulfur (S) in soybean leaf sampled at R2 stage intercropped with forages affected by soil acidity correction and soil amelioration by the application of lime and gypsum

\begin{tabular}{llllll}
\hline Factors & $\mathrm{P}$ & $\mathrm{K}$ & $\mathrm{Ca}$ & $\mathrm{Mg}$ & $\mathrm{S}$ \\
\hline Soybean+Forages (S) & $0.96^{\mathrm{ns}}$ & $1.21^{\mathrm{ns}}$ & $0.25^{\mathrm{ns}}$ & $0.87^{\mathrm{ns}}$ & $0.11^{\mathrm{ns}}$ \\
Soil Correction (C) & $7.49^{* *}$ & $1.69^{\mathrm{ns}}$ & $10.34^{* *}$ & $23.36^{* *}$ & $0.74^{\mathrm{ns}}$ \\
S X C & $0.75^{\mathrm{ns}}$ & $0.65^{\mathrm{ns}}$ & $1.10^{\mathrm{ns}}$ & $0.87^{\mathrm{ns}}$ & $0.69^{\mathrm{ns}}$ \\
C.V. $(\%)$ & 12.7 & 15.3 & 11.6 & 14.0 & \\
\hline
\end{tabular}

Note. ${ }^{*}$ Significant at the $P=0.05$ probability level; ${ }^{*}$ Significant at the $P=0.01$ probability level; ${ }^{\text {ns }}$ no significance; C.V. $=$ Coefficient of variance.

Forages intercropped with soybean did not affected nutrient concentration in soybean leaves. Regarding the effect of soil correction and amelioration, there was a significant effect only to $\mathrm{P}, \mathrm{Ca}$ and $\mathrm{Mg}$ concentrations in soybean leaf, showing that soil correction and amelioration increase the $\mathrm{P}, \mathrm{Ca}$ and $\mathrm{Mg}$ uptake (Table 5). The concentrations of $\mathrm{P}, \mathrm{Ca}$ and $\mathrm{Mg}$ were not influenced by forages intercropped with soybeans; however the concentration values found were considered above the sufficiency level recommended by Sousa \& Lobato (2004), which is $0.25,1.00$ and $0.40 \mathrm{dag} \mathrm{kg}^{-1}$ respectively for $\mathrm{P}, \mathrm{Ca}$ and $\mathrm{Mg}$. Highest $\mathrm{P}$ concentration values in soybean leaf were found in the treatments with lime and gypsum application. Potassium and S concentration in soybean leaf were not affected by either forages intercropped nor lime and gypsum application. Similarly to P, K concentration in soybean leaf was found values above the sufficiency level of $1.70 \mathrm{dag} \mathrm{kg}^{-1}$ of K. Sufficiency levels of $\mathrm{P}$ in soybean leaf in treatments with application of lime and gypsum was accompanied by increases in nutrient availability, being significantly related to reduction of soil acidity that causes $\mathrm{P}$ solubilization from solid phase to soil solution (Caires \& Fonseca, 2000; Caires et al., 2001; Inagaki et al., 2016). K and S absorption was not influenced by soil correction, mostly due to absence of liming and gypsum effect on nutrient content of soil, and because part of S can also be uptake from subsoil or by mineralization of organic matter (Caires \& Fonseca, 2000; Inagaki et al., 2016). As well as there was adequate forage aboveground biomass production (Table 1), the residue decomposition and mineralization was sufficient to supply the nutrients and attained the sufficiency levels. Calcium $(\mathrm{Ca})$ and magnesium $(\mathrm{Mg})$ concentration in soybean leaf increased due to application of lime and gypsum. The increased of nutrient uptake was caused by changes in root growth and by changes in nutrient availability. It is important to emphasizes that the nutrient dynamics in soils under no-till changes over the time and more growing seasons is important to evaluate and measure the impact of continuous crop residue addition annually and its effects on nutrient dynamics and also nutrient uptake by either cash or cover crops. To obtain more concrete results is necessary to evaluate this system for more harvest years. 
Table 5. Concentration of phosphorus $(\mathrm{P})$, potassium $(\mathrm{K})$, calcium $(\mathrm{Ca})$, magnesium $(\mathrm{Mg})$ and sulfur $(\mathrm{S})$ in soybean leaf sampled at R2 stage intercropped with forages affected by soil acidity correction and soil amelioration by the application of lime and gypsum ${ }^{\S}$

\begin{tabular}{|c|c|c|c|c|c|c|c|c|c|c|c|c|c|c|c|}
\hline \multirow{2}{*}{$\begin{array}{l}\text { Forage species intercropped } \\
\text { with soybean }\end{array}$} & \multicolumn{15}{|c|}{ Soil Correction/Amelioration $^{\S \S}$} \\
\hline & ${ }^{*}$ No LG & LG & Mean & No LG & LG & Mean & No LG & LG & Mean & No LG & LG & Mean & No LG & LG & Mean \\
\hline & \multicolumn{3}{|c|}{---- P $\left(\right.$ dag kg $\left.^{-1}\right)$---- } & \multicolumn{3}{|c|}{--- K (dag kg $\left.{ }^{-1}\right)$--- } & \multicolumn{3}{|c|}{--- $\mathrm{Ca}\left(\mathrm{dag} \mathrm{kg}{ }^{-1}\right)$--- } & \multicolumn{3}{|c|}{--- $\mathrm{Mg}\left(\mathrm{dag} \mathrm{kg}^{-1}\right)$--- } & \multicolumn{3}{|c|}{--- $\mathrm{S}\left(\right.$ dag kg $\left.^{-1}\right)$--. } \\
\hline tha & 0.27 & 0.26 & 0.27 & 2.03 & 1.88 & 1.95 & 1.25 & 1.23 & 1.24 & 0.42 & 0.41 & 0.41 & 0.21 & 0.18 & 0.20 \\
\hline & 0.30 & & 0.30 & 2.03 & 2.18 & 2.10 & 1.11 & 1.33 & 1.22 & 0.36 & 0.45 & 0.41 & 0.20 & 0.20 & 0.20 \\
\hline 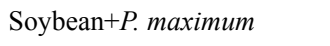 & 0.20 & 0.02 & 0.50 & 1.98 & 2.40 & 2.19 & 1.17 & 1.38 & 1.28 & 0.40 & 0.49 & 0.45 & 0.19 & 0.22 & 0.20 \\
\hline S & 0.27 & 0.30 & 0.29 & 1.78 & 1.90 & 1.84 & 1.28 & 1.30 & 1.29 & 0.42 & 0.48 & 0.45 & 0.20 & 0.21 & 0.20 \\
\hline & 0.29 & 0.30 & 0.30 & 1.90 & 1.93 & 1.91 & 1.10 & 1.35 & 1.23 & 0.37 & 0.46 & 0.41 & 0.21 & 0.21 & 0.21 \\
\hline So & 0.26 & 0.32 & 0.29 & 2.05 & 2.08 & 2.06 & 1.23 & 1.28 & 1.25 & 0.35 & 0.45 & 0.40 & 0.20 & 0.22 & 0.21 \\
\hline- & 0.28 & 0.33 & 0.30 & 1.98 & 2.13 & 2.05 & 1.18 & 1.33 & 1.25 & 0.37 & 0.47 & 0.42 & 0.19 & 0.22 & 0.20 \\
\hline (1) & $0.28 \mathrm{~B}$ & $0.31 \mathrm{~A}$ & 0.29 & 1.96 & 2.07 & 2.01 & $1.19 \mathrm{~B}$ & $1.31 \mathrm{~A}$ & 1.25 & $0.38 \mathrm{~B}$ & $0.46 \mathrm{~A}$ & 0.42 & 0.20 & 0.21 & 0.20 \\
\hline
\end{tabular}

Note. ${ }^{\S}$ Means followed by the same lowercase letters in the columns and uppercase letters in the rows are not significant (Tukey $P=0.05$ probability level; ${ }^{\S}$ no LG (no lime and no gypsum application), LG (lime and gypsum application).

\section{Conclusion}

Forage aboveground biomass in $P$. maximum yield highest biomass production among forages and the no application of lime and gypsum does not affect forages aboveground biomass. Soybean yield is not affected by intercropping with forages oversowed in soybean at R5 stage; however, the application of lime and gypsum increases soybean yield compared to no application of lime and gypsum. Nutrient concentration in soybean is not affected by intercropping while the application of lime and gypsum increases the uptake of $\mathrm{P}, \mathrm{Ca}$ and $\mathrm{Mg}$. The study site is located in a region with large areas with cattle production under pasture and mostly degraded pasture due the inadequate pasture management. On the other hand, soybean is increasing in the same region and a win-win scenario is taking place, where soybean production increases soil nutrient status due to nutrient management, increasing forages aboveground biomass, which forages can be used in both cases as cover crops to establish no-till and also as forages for integrated crop-livestock.

\section{References}

Alves, B. J. R., Madari, B. E., \& Boddey, R. M. (2017). Integrated crop-livestock-forestry systems: Prospects for a sustainable agricultural intensification. Nutrient Cycling in Agroecosystems, 108, 1-4. https://doi.org/ 10.1007/s10705-017-9851-0

Andrade, C. A. O., Borghi, E., Bortolon, L., Bortolon, E. S. O., Camargo, F. P., Avanzi, J. C., ... Fidelis, R. R. (2017). Straw production and agronomic performance of soybean intercropped with forage species in no-tillage system. Pesquisa Agropecuária Brasileira, 52, 861-868. https://doi.org/10.1590/S0100-204X 2017001000005

Bahry, C. A., Venske, E., Nardino, M., Zimmer, P. D., Souza, V. Q., \& Caron, B. O. (2013). Desempenho agronômico da soja em função da desfolha em diferentes estádios vegetativos. Tecnologia \& Ciência Agropecuária, 7, 19-24.

Batisti, R., \& Sentelhas, P. C. (2017). Improvement of Soybean resilience to drought through deep root system in Brazil. Agronomy Journal, 109, 1612-1622. https://doi.org/10.2134/agronj2017.01.0023

Boer, C. A., Assis, R. L., Silva, G. P., Braz, A. J. B. P., Barroso, A. L. L., Cargnelutti Filho, A., \& Pires, F. R. (2008). Biomassa, decomposição e cobertura do solo ocasionada por resíduos culturais de três espécies vegetais na região centro-oeste do Brasil. Revista brasileira de Ciência do Solo, 32, 843-851. https://doi.org/10.1590/S0100-06832008000200038

Braz, F. P., Mion, T. D., \& Gameiro, A. H. (2012). Análise socioeconômica comparativa de sistemas de integração lavoura-pecuária em propriedades rurais nas regiões sul, sudeste e centro-oeste do Brasil. Informações Econômicas, 42(2), 69-82. Retrieved from http://posvnp.org/novo/wp-content/uploads/2014/11/Braz_FP.pdf 
Caires, E. F., \& Fonseca, A. F. (2000). Absorção de nutrientes pela soja cultivada no sistema de plantio direto em função da calagem na superfície. Bragantia, 59, 213-220. https://doi.org/10.1590/S0006-87052000000 200013

Caires, E. F., Fonseca, A. F., Feldhaus, I. C., \& Blum, J. (2001). Crescimento radicular e nutrição da soja cultivada no sistema plantio direto em resposta ao calcário e gesso na superfície. Revista brasileira de Ciência do Solo, 25, 1029-1040. https://doi.org/10.1590/S0100-06832001000400025

Calonego, J. C., Borghi, E., \& Crusciol, C. A. C. (2011). Intervalo hídrico ótimo e compactação do solo com cultivo consorciado de milho e braquiária. Revista Brasileira de Ciência do Solo, 35, 2183-2190. https://doi.org/10.1590/S0100-06832011000600033

Calonego, J. C., Gil, F. C., Rocco, V. F., \& Santos, E. A. (2012). Persistência e liberação de nutrientes da palha de milho, braquiária e labe-labe. Biosciense Journal, 28, 770-781.

Carvalho, A. M., Souza, L. L. P., Guimarães Júnior, R., Alves, P. C. A. C., \& Vivaldi, L. J. (2011). Cover plants with potential use for crop-livestock integrated systems in the Cerrado region. Pesquisa Agropecuária Brasileira, 46, 1200-1205. https://doi.org/10.1590/S0100-204X2011001000012

Chioderoli, C. A., Melo, L. M. M., Grigolli, P. J., Furlani, C. E. A., Silva, J. O. R., \& Cesarin, A. L. (2012). Atributos físicos do solo e produtividade de soja em sistema de consórcio milho e braquiária. Revista Brasileira de Engenharia Agrícola e Ambiental, 16, 37-43. https://doi.org/10.1590/S1415-436620120001 00005

CONAB (Companhia Nacional de Abastecimento). (2014). Acompanhamento da safra 2013/2014: Sexto levantamento (p. 23). Palmas.

EMBRAPA (Empresa Brasileira de Pesquisa Agropecuária). (2014). Sistema brasileiro de classificação dos solos (3rd ed.). Rio de Janeiro, RJ: EMBRAPA.

Fageria, N. K., \& Nascente, A. S. (2014). Management of soil acidity of South American soils for sustainable production. In D. Sparks (Ed.), Advances in Agronomy (pp. 221-277). Amsterdam, Netherlands: Elsevier. https://doi.org/10.1016/B978-0-12-802139-2.00006-8

Fidelis, R. R., Rocha, R. N. C., Leite, U. T., \& Tancredi, F. D. (2003). Alguns aspectos do plantio direto para a cultura da soja. Bioscience Journal, 19, 23-31.

Franzluebbers, A. J., Lemaire, G., Carvalho, P. C. F., Sulc, R. M., \& Dedieu, B. (2014). Toward agricultural sustainability through integrated crop-livestock systems: Environmental outcomes. Agriculture, Ecosystems \& Environment, 190, 1-3. https://doi.org/10.1016/j.agee.2014.04.028

Garcia, C. M. P., Andreotti, M., Teixeira Filho, M. C. M., Lopes, K. S. M., \& Buzetti, S. (2014). Decomposição da palhada de forrageiras em função da adubação nitrogenada após o consórcio com milho e produtividade da soja em sucessão. Bragantia, 73, 143-152. https://doi.org/10.1590/brag.2014.016

Guimarães, G. L., Buzetti, S., Silva, E. C., Lazarini, E., \& Sá, M. E. (2003). Culturas de inverno e pousio na sucessão da cultura da soja em plantio direto. Acta Scientiarum. Agronomy, 25, 339-344. https://doi.org/ 10.4025/actasciagron.v25i2.1918

Inagaki, T. M., Sá, J. C. M., Caires, E. F., \& Gonçalves, D. R. P. (2016). Lime and gypsum application increases biological activity, carbon pools, and agronomic productivity in highly weathered soil. Agriculture, Ecosystems \& Environment, 231, 156-165. https://doi.org/10.1016/j.agee.2016.06.034

Izumi, Y., Yoshida, T., \& Iijima, M. (2009). Effects of Subsoiling to the Non-tilled Field of Wheat-Soybean Rotation on the Root System Development, Water Uptake, and Yield. Plant Production Science, 12, 327-335. https://doi.org/10.1626/pps.12.327

Köppen, W. (1948). Climatologia: con un estudio de los climas de la tierra. Fondo de Cultura Econômica (p. 479). México.

Krutzmann, A., Cecato, U., Silva, P. A., Tormena, C. A., Iwamoto, B. S., \& Martins, E. N. (2013). Palhadas de gramíneas tropicais e rendimento da soja no sistema de integração lavoura-pecuária. Bioscience Journal, 29, 842-851.

Lemaire, G., Franzluebbers, A. J., Carvalho, P. C. F., \& Dedieu, B. (2014). Integrated crop-livestock systems: Strategies to achieve synergy between agricultural production and environmental quality. Agriculture, Ecosystems \& Environment, 190, 4-8. https://doi.org/10.1016/j.agee.2013.08.009 
Litch, M. (2014). Soybean growth and development (Ver. 2014). Ames, IA: Iowa State University Extension and Outreach.

Machado, L. A. Z., \& Assis, P. G. G. (2010). Produção de palha e forragem por espécies anuais e perenes em sucessão à soja. Pesquisa Agropecuária Brasileira, 45, 415-422. https://doi.org/10.1590/S0100-204X 2010000400010

Malavolta, E., Vitti, G. C., \& Oliveira, S. A. (1997). Avaliação do estado nutricional das plantas-Princípios e aplicações (2nd ed.). Piracicaba, SP: IPNI.

Maltas, A., Corbeels, M., Scopel, E., Wery, J., \& Silva, F. A. M. (2009). Cover crop and nitrogen effects on maize productivity in no-tillage systems of the Brazilian Cerrados. Agronomy Journal, 101, 1036-1046. https://doi.org/10.2134/agronj2009.0055

Mancin, C. R., Souza, L. C. F., Novelino, J. O., Marchetti, M. E., \& Gonçalves, M. C. (2009). Desempenho agronômico da soja sob diferentes rotações e sucessões de culturas em sistema plantio direto. Acta Scientiarum. Agronomy, 31, 71-77. https://doi.org/10.4025/actasciagron.v31i1.6631

Mata, J. F., Silva, R. R., Chagas, J. F. R., Freitas, G. A., \& Farias, V. L. S. (2011). Produção, decomposição e meia-vida da palhada de consórcio de gramíneas sob diferentes níveis de adubação para sistema de plantio direto no cerrado. Revista Brasileira de Tecnologia Aplicada nas Ciências Agrárias, 4, 96-115. https://doi.org/10.5777/PAeT.V4.N1.06

Moore, E. B., Wiedenhoeft, M. H., Kaspar, T. C., \& Cambardella, C. A. (2014). Rye cover crop effects on soil quality in no-till corn silage-soybean cropping systems. Soil Science Society of America Journal, 78, 968-976. https://doi.org/10.2136/sssaj2013.09.0401

Muraishi, C. T., Leal, A. J. F., Lazarini, E., Rodrigues, L. R., \& Gomes Junior, F. G. (2005). Manejo de espécies vegetais de cobertura do solo e produtividade do milho e da soja em semeadura direta. Acta Scientiarum. Agronomy, 27, 199-207. https://doi.org/10.4025/actasciagron.v27i2.1903

Nolan, R. L., Wells, M. S., Sheaffer, C. C., Baker, J. M., Martinson, K. L., \& Coulter, J. A. (2017). Establishment and function of cover crops interseeded into corn. Crop Science, 58, 863-873. https://doi.org/10.2135/ cropsci2017.06.0375

Pacheco, L. P., Barbosa, J. M., Leandro, W. M., Machado, P. L. O. A., Assis, R. L., Madari, B. E., \& Petter, F. A. (2013). Ciclagem de nutrientes por plantas de cobertura e produtividade de soja e arroz em plantio direto. Pesquisa Agropecuária Brasileira, 48, 1228-1236. https://doi.org/10.1590/S0100-204X2013000900006

Pacheco, L. P., Pires, F. R., Monteiro, F. P., Procópio, S. O., Assis, R. L., Cargnelutti Filho, A., ... Petter, F. A. (2009). Sobressemeadura da soja como técnica para supressão da emergência de plantas daninhas. Planta Daninha, 27, 455-463. https://doi.org/10.1590/S0100-83582009000300005

Pariz, C. M., Costa, C., Crusciol, C. A., Meireles, P. R., Castilhos, A. M., Andreotti, M., ... Franzluebbers, A. (2017). Production, nutrient cycling and soil compaction to grazing of grass companion cropping with corn and soybean. Nutrient Cycling in Agroecosystems, 108, 35-54. https://doi.org/10.1007/s10705-016-9821-y

Passos, A. M. A., Rezende, P. M., Reis, W. P., \& Botrel, E. P. (2015). Cultivares de soja em sucessão ao trigo nos sistemas convencional e plantio direto. Revista Agrarian, 8, 30-38.

Pauletti, V., Lima, M. R., Barcik, C., \& Bittencourt, A. (2003). Rendimento de grãos de milho e soja em sucessão cultural de oito anos sob diferentes sistemas de manejo de solo e de culturas. Ciência Rural, 33, 491-495. https://doi.org/10.1590/S0103-84782003000300015

Pedersen, P., \& Lauer, J. G. (2004). Response of soybean yield componentes to management system and planting date. Agronomy Journal, 96, 1372-1381. https://doi.org/10.2134/agronj2004.1372

Pereira, R. G., Albuquerque, A. W., Souza, R. O., Silva, A. D., Santos, J. P. A., Barros, E. S., \& Medeiros, P. V. Q. (2011). Sistemas de manejo do solo: Soja [Glycine max (L.)] consorciada com Brachiaria decumbens (STAPF). Pesquisa Agropecuária Tropical, 41, 44-51. https://doi.org/10.5216/pat.v41i1.6981

Peron, A. J., \& Evangelista, A. R. (2004). Degradação de Pastagens em Regiões de Cerrado. Ciência e Agrotecnologia, 28, 655-661. https://doi.org/10.1590/S1413-70542004000300023

Santos, H. P., Fontaneli, R. S., Spera, S. T., \& Maldaner, G. L. (2013). Rendimento de grãos e em diferentes sistemas de produção integração Lavoura-Pecuária. Revista Brasileira de Ciências Agrárias, 8, 49-56. https://doi.org/10.1590/1678-4499.0153 
Santos, H. P., Lhamby, J. C. B., \& Spera, S. T. (2006). Rendimento de grãos de soja em função de diferentes sistemas de manejo de solo e de sucessão de culturas. Ciência Rural, 36, 21-29. https://doi.org/10.1590/ S0103-84782006000100004

Sievers, T., \& Cook, R. L. (2018). Aboveground and root decomposition of cereal rye and hairy vetch cover crops. Soil Science Society of America Journal, 82, 147-155. https://doi.org/10.2136/sssaj2017.05.0139

Silva, A. R., Sales, A., \& Veloso, C. A. C. (2015). Desenvolvimento da Soja em Sistemas de Integração Lavoura-pecuária-Floresta. Enciclopédia Biosfera, Centro Científico Conhecer, 11, 896-904. https://doi.org/ 10.18677/Enciclopedia_Biosfera_2015_129

Silva, F. A. S., \& Azevedo, C. A. V. (2016). The Assistat software version 7.7 and its use in the analysis of experimental data. African Journal of Agricultural Research, 11(39), 3733-3740. https://doi.org/10.5897/ AJAR2016.11522

Singer, J. W., Logsdon, S., \& Meek, D. W. (2008). Soybean growth and seed yield response to tillage and compost. Agronomy Journal, 100, 1039-1046. https://doi.org/10.2134/agronj2007.0360

Sousa, D. M. G., \& Lobato, E. (2004). Correção do solo e adubação (2nd ed.). Brasília, DF: Embrapa Informação Tecnológica.

Spera, S. T., Escosteguy, P. A. V., Denardin, J. E., Klein, V. A., \& Santos, H. P. (2011). Atributos químicos restritivos de Latossolo Vermelho distrófico e tipos de manejo de solo e rotação de culturas. Agrarian, 4, 324-333.

Tormena, C. A., Karlen, D. L., Logsdon, S., \& Cherubin, M. R. (2016). Visual soil structure effects of tillage and corn stover harvest in Iowa. Soil Science Society of America Journal, 80, 720-726. https://doi.org/10.2136/ sssaj2015.12.0425

Yagi, R., Ferreira, M. E., Cruz, M. C. P., Barbosa, J. C., \& Araujo, L. A. N. (2005). Soil organic matter as a function of nitrogen fertilization in crop successions. Scientia Agricola, 62, 374-380. https://doi.org/10.1590/ S0103-90162005000400011

\section{Copyrights}

Copyright for this article is retained by the author(s), with first publication rights granted to the journal.

This is an open-access article distributed under the terms and conditions of the Creative Commons Attribution license (http://creativecommons.org/licenses/by/4.0/). 